DOI.

https://doi.org/10.22219/fths.v2i1

Received: November 2018

Accepted: Desember 2018

Available online: Februari 2019

\title{
Kajian Konsentrasi Pati Singkong Karet (Manihot glaziovii) dan Penambahan Fraksi Oleat dan Asam Oleat pada Karakteristik Fisik dan Barrier Edible Film
}

\author{
Anik Wahyuningsih ${ }^{1}$, Warkoyo ${ }^{1^{*}}$, Damat ${ }^{1}$ \\ 1 Program Studi Ilmu dan Teknologi Pangan, Fakultas Pertanian Peternakan Universitas \\ Muhammadiyah Malang, Malang, Indonesia \\ *Corresponding author email : warkoyo@umm.ac.id
}

\begin{abstract}
Edible film can be an alternative packing of safe and biodegradable products. The utilization of ceara rubber starch (Manihot glaviovii) as an edible film making material with the addition of oleic fraction and oleic acid is expected to improve the characteristic of starch-based edible film. The purpose of this study are: (i) to know the existence of interaction between treatment of ceara starch concentration and addition of oleic fraction and oleic acid on physical characteristics and barrier of edible film, (ii) to know the effect of treatment of ceara starch concentration on physical characteristics and barrier of edible film, and (iii) to know the effect of oleic fraction and oleic acid addition on physical characteristics and barrier of edible film. This research uses Randomized Completely Block Design (RCBD) factorial composed of two factors. The first factor was the difference in the concentration of the ceara rubber starch consisting of 3 levels $13 \%$, $4 \%$ and $5 \%$ ) and the second factor was the addition of lipids (0\% lipid, 15\% RBDPO, and $15 \%$ oleic acid (w/w polymer)) with 3 repetitions. Parameters measured were thickness, transparency, water vapor transmission rate (WVTR), elasticity, tensile strength, solubility and microstructure of edible film.The results showed that there was an interaction between the concentration of ceara rubber starch with the lipid addition of in WVTR, elasticity, and tensile strength parameter of edible film. The concentration of ceara rubber starch has a significantly effect on the parameters of thickness, transparency, and solubility. Addition of lipids significantly affected the parameters of thickness, transparency, and WVTR. The best treatment was obtained P2A3 (4\% ceara rubber starch $+15 \%$ oleic acid) with average thickness of $0.133 \mathrm{~mm}$, transparency 0.818 $\mathrm{a} / \mathrm{mm}, 17.246 \mathrm{~g} / \mathrm{m} 2$.day water vapor transmission rate, $48.781 \%$ elasticity, tensile strength $1.458 \mathrm{MPa}$, and $44.035 \%$ solubility.
\end{abstract}

Keywords: Ceara rubber, edible film, lipid

\section{PENDAHULUAN}

Penggunaan plastik sebagai pengemas makanan memberikan dampak negatif pada produk dan lingkungan. Kesadaran masyarakat yang semakin tinggi akan pentingnya konsumsi makanan yang sehat dan aman serta kepedulian terhadap lingkungan, membuka peluang bagi penerapan teknologi pengawetan pangan, antara lain melalui pengemasan dengan edible film. Edible 
film memberikan alternatif bahan pengemas yang tidak berdampak pada pencemaran lingkungan karena menggunakan bahan yang dapat diperbaharui dan harganya murah. Singkong karet (Manihot glaziovii) merupakan jenis singkong pahit yang mengandung senyawa beracun yaitu asam sianida (HCN) dalam kadar tinggi yakni sekitar $>100 \mathrm{mg} / \mathrm{kg}$. Pada kenyataannya, ada korelasi antara kadar HCN singkong dengan kandungan pati. Semakin tinggi kadar HCN singkong, maka semakin meningkat pula kadar pati (Balitbang Pertanian, 2011). Salah satu cara untuk meningkatkan daya guna singkong karet adalah dengan memanfaatkan pati singkong karet sebagai bahan pembuatan edible film.

Kelebihan utama pati sebagai edible film yaitu sifat penghalang yang sangat baik terhadap gas dan transmisi zat terlarut. Namun, edible film dari pati memiliki kelemahan yaitu permeabilitas yang tinggi terhadap transfer uap air, sehingga membatasi pemanfaatannya sebagai bahan kemasan (Falguera et al., 2011). Salah satu upaya untuk meningkatkan sifat barrier edible film dari pati yaitu dengan penambahan zat aditif seperti lipid, lilin, atau minyak essensial (Pamilia dkk., 2014). Zat aditif yang digunakan pada umumnya berupa lipid. Salah satu alasan lipid sering ditambahkan dalam formula film, karena lipid memberikan sifat hidrophobik. Salah satu lipid yang paling mudah diperoleh adalah minyak goreng/Refined, Bleached and Deodorized Palm Oil (RBDPO) dengan fraksi oleat. Selain itu, menurut Tanaka et al. (2001), penambahan asam oleat pada edible film memberikan nilai terbaik pada semua parameter. Berdasarkan uraian di atas, maka perlu adanya penelitian untuk mengetahui konsentrasi pati singkong karet dan penambahan lipid yang tepat pada pembuatan edible film agar diperoleh karakteristik yang baik. Penelitian ini bertujuan untuk: (i) mengetahui ada tidaknya interaksi antara perlakuan konsentasi pati singkong karet dan penambahan fraksi oleat dan asam oleat pada karakteristik fisik dan barrier edible film, (ii) mengetahui pengaruh perlakuan konsentrasi pati singkong karet pada karakteristik fisik dan barrier edible film, dan (iii) mengetahui pengaruh penambahan fraksi oleat dan asam oleat pada karakteristik fisik dan barrier edible film

\section{METODE PENELITIAN}

\section{Bahan}

Bahan yang digunakan dalam penelitian ini adalah singkong karet, gliserol teknis, asam oleat teknis, RBDPO, dan aquades.

Alat

Peralatan yang digunakan dalam penelitian ini adalah hot plate stirrer, loyang plastik 15 x $15 \mathrm{~cm}$, cabinet dryeroven WTC Binder 7200 Tutlingen/ 
German typ:E53, Spektrofotometer Genesys 20 Thermo Spectronik, tekstur analyzer Shimizu, mikrometer sekrup Herma,

\section{Pembuatan Pati Singkong Karet}

Pembuatan pati singkong mengacu pada Cui (2005) dengan modifikasi. Singkong karet dikupas lalu dicuci menggunakan air mengalir untuk menghilangkan lendir di bawah kulit. Kemudian singkong diparut menggunakan pemarut tradisional. Penghalusan ini untuk mempermudah proses ekstraksi pati. Kemudian menambahkan air dengan perbandingan 5:1 dari jumlah singkong sehingga menjadi bubur untuk mengekstrak pati singkong. Bubur yang dihasilkan diremas-remas dan disaring menggunakan kain saring sehingga dihasilkan suspensi pati. Suspensi pati ditampung dalam wadah dan dilakukan pengendapan selama 24 jam. Endapan pati yang diperoleh tersebut diletakkan dalam loyang dan dikeringkan dalam cabinet dryer. Pengeringan dilakukan pada suhu $50^{\circ} \mathrm{C}$ selama 6 jam. Pati yang dihasilkan kemudian diblender hingga halus dan diayak menggunakan saringan 100 mesh.

\section{Pembuatan Edible Film}

Pembuatan pati singkong mengacu pada Pangesti dkk (2014) dengan modifikasi. Pati singkong karet ditimbang masing-masing sebanyak 3\%; 4\%; 5\% (b/v), dan gliserol 15\% (b/b polimer). Kemudian kedua bahan dilarutkan dengan aquades hingga volumenya $100 \mathrm{ml}$. Masing-masing larutan edible film kemudian dipanaskan hingga suhunya mencapai $70^{\circ} \mathrm{C}$ selama 4 menit. Selanjutnya, lipid ditambahkan yakni 0\% lipid; 15\% minyak kelapa sawit; dan 15\% asam oleat (b/b polimer) pada kondisi yang sama. Larutan edible film kemudian diaduk secara manual menggunakan sendok selama satu menit. Larutan dituangkan dalam loyang ukuran $15 \times 15 \mathrm{~cm}$ dan diratakan sehingga diperoleh ketebalan yang sama. Edible film kemudian dikeringkan dalam cabinet dryer dengan suhu $50{ }^{\circ} \mathrm{C}$ selama 24 jam. Setelah kering, film didinginkan pada suhu ruang selama 15 menit, film kemudian dilepas dari plate plastik. Selanjutnya, edible film dianalisis karakteristik fisik, mekanik dan sensorisnya.

\section{Parameter Penelitian}

Pati sebagai bahan baku pembuatan edible film terlebih dahulu dilakukan analisis terhadap komposisi kimianya antara lain kadar air, kadar amilosa dan amilopektin. Sedangkan untuk karakterisasi fisik dan barrier Edible Film meliputi beberapa parameter, yaitu: ketebalan, laju transmisi uap air, kuat tarik (tensile strength), perpanjangan (elastisitas), transparansi dan kelarutan.

\section{Rancangan Percobaan dan Analisa Data}

Penelitian ini akan memiliki dua tahapan, yaitu tahapan pembuatan pati singkong karet dan pembuatan edible film. Penelitian ini menggunakan Rancangan Acak Kelompok (RAK) faktorial dengan dua faktor. Faktor pertama adalah konsentrasi pati singkong karet yaitu $3 \%$ b/v (P1), 4\% b/v (P2), dan $5 \%$ b/v 
(P3). Faktor kedua adalah penambahan lipid yaitu $0 \%$ lipid b/b polimer (A1), 15\% RBDPO (fraksi oleat) b/b polimer (A2), dan $15 \%$ asam oleat b/b polimer (A3) dengan pola faktorial $3 \times 3$, setiap perlakuan diulang sebanyak 3 kali sehingga diperoleh 27 satuan percobaan.

Data yang diperoleh dianalisis dengan menggunakan Analysis of Variant (ANOVA). Uji lanjut yang digunakan adalah uji DMRT taraf $\alpha=5 \%$ dengan taraf nyata $5 \%(\alpha=0,05)$.

\section{HASIL DAN PEMBAHASAN Ketebalan}

Berdasarkan hasil penelitian diketahui bahwa tidak terdapat interaksi antara konsentrasi pati singkong karet dan penambahan fraksi oleat dan asam oleat pada ketebalan edible film. Namun, perlakuan konsentrasi pati singkong karet dan penambahan RBDPO (fraksi oleat) dan asam oleat berpengaruh terhadap ketebalan edible film yang dihasilkan. Berdasarkan Tabel 1, diketahui bahwa perlakuan pati singkong karet 3\% memiliki angka ketebalan edible film terendah yakni $0,094 \mathrm{~mm}$ jika dibandingkan dengan perlakuan pati singkong karet 4\% dan pati singkong karet 5\%. Perlakuan P3 memiliki angka ketebalan tertinggi. Hasil penelitian menunjukkan bahwa semakin tinggi konsentrasi pati singkong karet yang ditambahkan, maka makin meningkat pula ketebalan edible film yang dihasilkan. Penambahan jumlah pati yang semakin besar akan meningkatkan polimer penyusun matriks film, total padatan edible film semakin besar sehingga film yang dihasilkan akan semakin tebal. (Warkoyo dkk., 2014). Barus (2002) menyebutkan ketebalan edible film dipengaruhi oleh total padatan yang terdapat dalam suspensi, volume larutan, dan luas cetakan yang digunakan.

Rerata ketebalan yang dihasilkan oleh penambahan lipid diketahui bahwa perlakuan 0\% lipid memiliki nilai ketebalan terendah yakni 0,110 $\mathrm{mm}$. Perlakuan 15\% RBDPO dan 15\% asam oleat memberikan ketebalan tertinggi. Penambahan lipid yakni fraksi oleat dan asam oleat menghasilkan edible film yang lebih tebal dibandingkan tanpa penambahan lipid. ketebalan, permeabilitas dan kelarutan edible film merupakan karakteristik yang pada umumnya dipengaruhi oleh konsentrasi bahan keringnya (Hawa dkk., 2015). Rahim dkk (2010) juga menunjukkan bahwa semakin banyak minyak sawit yang ditambahkan maka film yang dihasilkan semakin tebal. Hal ini disebabkan karena ketebalan film dipengaruhi oleh banyaknya zat/padatan yang terlarut. 
Tabel 1. Rerata Ketebalan dan Transparansi Edible Film oleh Perlakuan Konsentrasi Pati Singkong Karet dan Penambahan RBDPO dan Asam Oleat

\begin{tabular}{|c|c|c|}
\hline Perlakuan & Ketebalan (mm) & Transparansi (a/mm) \\
\hline \multicolumn{3}{|c|}{ Konsentrasi Pati Singkong Karet (\% b/v) } \\
\hline 3 & $0,094^{\mathrm{a}}$ & $0,46^{\mathrm{a}}$ \\
\hline 4 & $0,124^{\mathrm{b}}$ & $0,59^{b}$ \\
\hline 5 & $0,148^{\mathrm{c}}$ & $0,66^{\mathrm{b}}$ \\
\hline \multicolumn{3}{|c|}{ Penambahan RBDPO dan Asam Oleat (\% b/b polimer) } \\
\hline 0\% Lipid & $0,110^{\mathrm{a}}$ & $0,28^{\mathrm{a}}$ \\
\hline $15 \% \mathrm{RBDPO}$ & $0,125^{\mathrm{b}}$ & $0,61^{b}$ \\
\hline 15\% Asam Oleat & $0,132^{\mathrm{b}}$ & $0,82^{\mathrm{c}}$ \\
\hline
\end{tabular}

Keterangan: Angka-angka yang diikuti oleh huruf yang sama menunjukkan perbedaan yang tidak nyata menurut Duncan a 5\%

\section{Transparansi}

Berdasarkan hasil penelitian diketahui bahwa tidak terdapat interaksi antara konsentrasi pati singkong karet dan penambahan lipid terhadap ketebalan edible film yang dihasilkan. Namun, perlakuan konsentrasi pati singkong karet dan penambahan RBDPO (fraksi oleat) dan asam oleat berpengaruh terhadap transparansi edible film yang dihasilkan. Berdasarkan Tabel 1, diketahui bahwa perlakuan pati singkong karet 3\% memiliki nilai transparansi edible film terendah yakni $0,46 \mathrm{a} / \mathrm{mm}$. Perlakuan pati singkong karet $4 \%$ dan pati singkong karet 5\% memberikan transparansi tertinggi. Peningkatan konsentrasi pati singkong karet menyebabkan edible film yang dihasilkan menjadi lebih tidak transparan dengan nilai transparansi yang meningkat. Transparansi dari suatu sampel akan sebanding dengan ketebalan dan konsentrasi. Bila ketebalan benda atau konsentrasi materi yang dilewati bertambah maka cahaya akan lebih banyak diserap. Jadi, transparansi berbanding lurus dengan ketebalan dan konsentrasi. Selain itu, faktor yang sedang mempengaruhi adalah jumlah bahan dari larutan yang diukur itu sendiri (Wiryawan, 2007).

Rerata transparansi yang dihasilkan oleh penambahan lipid diketahui bahwa perlakuan $0 \%$ lipid menghasilkan edible film terbaik dengan nilai transparansi terendah yakni $0,110 \mathrm{~mm}$. Sedangkan perlakuan $15 \%$ asam oleat memiliki nilai transparansi tertinggi. Penambahan RBDPO (fraksi oleat) dan asam oleat mengakibatkan peningkatan nilai transparansi edible film. Hal ini dapat dipengaruhi oleh struktur internal lipid yang ditambahkan. RBDPO dengan komposisi asam lemak jenuh dan asam lemak tidak jenuh mampu menghasilkan dispersi yang lebih baik pada edible film dibandingkan asam oleat yang merupakan asam lemak tidak jenuh. Menurut Fabra et al. (2010), 
transparansi yang berbeda dari film berhubungan dengan struktur internal yang dikembangkan selama pengeringan film. Film yang mengandung lipid dari asam lemak jenuh menghasilkan film lebih transparan dari pada asam oleat. Hal ini disebabkan oleh dispersi asam lemak jenuh yang lebih baik dalam matriks pati dibandingkan dengan asam oleat. Dispersi asam lemak jenuh yang lebih baik dalam matriks hidrokoloid mungkin terkait dengan interaksi rantai asam lemak hidrofobik dengan fraksi pati yang berbeda.

\section{Laju Transmisi Uap Air/ Water Vapor Transmission Rate (WVTR)}

Berdasarkan hasil penelitian diketahui bahwa terdapat interaksi antara konsentrasi pati singkong karet dan penambahan lipid pada laju transmisi uap air edible film yang dihasilkan. Rerata WVTR edible film akibat konsentrasi pati singkong karet dengan penambahan RBDPO dan asam oleat disajikan pada Tabel 2.

Tabel 2. Rerata WVTR Edible Film Akibat Konsentrasi Pati Singkong Karet dengan Penambahan RBDPO dan Asam Oleat

\begin{tabular}{ll}
\hline Kombinasi Perlakuan & WVTR $\left(\mathrm{g} / \mathrm{m}^{2}\right.$. hari $)$ \\
\hline P1A1 (Pati singkong karet 3\% + 0\% lipid) & $33,463^{\mathrm{e}}$ \\
P1A2 (Pati singkong karet 3\% + 15\% RBDPO) & $30,467^{\mathrm{cd}}$ \\
P1A3 (Pati singkong karet 3\% + 15\% asam oleat) & $24,914^{\mathrm{b}}$ \\
P2A1 (Pati singkong karet 4\% + 0\% lipid) & $37,342^{\mathrm{f}}$ \\
P2A2 (Pati singkong karet 4\% + 15\% RBDPO) & $32,876^{\mathrm{de}}$ \\
P2A3 (Pati singkong karet 4\% + 15\% asam oleat) & $17,246^{\mathrm{a}}$ \\
P3A1 (Pati singkong karet 5\% + 0\% lipid) & $44,275^{\mathrm{g}}$ \\
P3A2 (Pati singkong karet 5\% + 15\% RBDPO) & $30,202^{\mathrm{c}}$ \\
P3A3 (Pati singkong karet 5\% + 15\% asam oleat) & $18,480^{\mathrm{a}}$ \\
\hline
\end{tabular}

Keterangan: Angka-angka yang diikuti oleh huruf yang sama menunjukkan perbedaan yang tidak nyata menurut Duncan a $5 \%$

Berdasarkan Tabel 2, diketahui bahwa WVTR terendah dihasilkan perlakuan P2A3 dengan rerata 17,246 g/m2.hari. Sedangkan WVTR tertinggi dihasilkan perlakuan P3A1 dengan rerata 44,275 g/m2.hari. Hal ini menunjukkan bahwa kombinasi perlakuan P2A3 menghasilkan edible film terbaik karena mampu mengurangi laju transmisi uap air tertinggi. Peningkatan konsentrasi pati singkong karet dalam pembuatan edible film cenderung meningkatkan transmisi uap air. Peningkatan pati akan diikuti dengan peningkatan amilosa yang dapat menyebabkan jumlah kelompok hidroksil bebas semakin banyak, yang mengakibatkan laju transmisi uap air semakin besar 
(Alves et al., 2007). Barus (2002) menambahkan bahwa rasio antara bagian yang hidrofilik dan hidrofobik komponen film akan memempengaruhi laju transmisi uap air film tersebut. Semakin besar hidrofilik film, maka nilai laju transmisi uap air juga semakin besar.

Penambahan RBDPO (fraksi oleat) dan asam oleat pada pembuatan edible film dengan konsentrasi yang sama mampu mengurangi laju transmisi uap air. Hal ini dikarenakan penambahan lipid yang bersifat hidrofobik mampu mengurangi kontak uap air dengan edible film. Asam oleat yang terdispersi dalam cellulose sulfate (CS) film mampu mengurangi area antarmuka praktis yang terpapar uap air. Dalam struktur $\mathrm{O} / \mathrm{W}$, ikatan hidrogen terbentuk antara gugus karboksil $(-\mathrm{COOH})$ pada asam oleat dan gugus hidroksil $(-\mathrm{OH})$ pada CS (Chen et al., 2015).

\section{Elatisitas}

Berdasarkan hasil penelitian diketahui bahwa terdapat interaksi antara konsentrasi pati singkong karet dan penambahan lipid terhadap elastisitas edible film yang dihasilkan. Rerata elastisitas edible film akibat konsentrasi pati singkong karet dengan penambahan RBDPO dan asam oleat disajikan pada Tabel 3.

Berdasarkan Tabel 3, diketahui bahwa elastisitas terendah adalah P1A3 dengan persen pemanjangan $41,326 \%$. Sedangkan elastisitas tertinggi adalah P2A1 dengan persen pemanjangan 55,236\%. Peningkatan konsentrasi pati singkong karet cenderung meningkatkan elastisitas sehingga edible film memiliki sifat lebih elastis dan tidak mudah patah. Syarifuddin dan Yunianti (2015) menjelaskan bahwa sifat fleksibilitas edible film dapat dipengaruhi oleh polaritas senyawa pembentuknya. Senyawa yang bersifat polar menyebabkan terjadinya ikatan antar air-polimer, sehingga ikatan antar polimer menjadi berkurang dan fleksibilitas meningkat. Peningkatan konsentrasi pati hingga 5\% menyebabkan penurunan elastisitas. Rahim dkk. (2010) juga melaporkan bahwa penurunan elongasi diduga karena adanya interaksi kuat antara molekul pati dengan meningkatnya konsentrasi pati aren. Ikatan yang terjadi antara molekul pati semakin rapat dan kompak sehingga akan menyebabkan edible film menjadi kuat dan menurunkan elastisitas. 
Tabel 3. Rerata Elastisitas dan Kuat Tarik Edible Film akibat Konsentrasi Pati Singkong Karet dengan Penambahan RBDPO dan Asam Oleat

\begin{tabular}{lll}
\hline Kombinasi Perlakuan & $\begin{array}{l}\text { Perpanjangan } \\
(\%)\end{array}$ & $\begin{array}{l}\text { Kuat Tarik } \\
(\mathrm{MPa})\end{array}$ \\
\hline P1A1 (Pati singkong karet 3\%+ 0\% lipid) & $45,961^{\mathrm{bcd}}$ & $0,496^{\mathrm{a}}$ \\
P1A2 (Pati singkong karet 3\% + 15\% RBDPO) & $43,573^{\mathrm{ab}}$ & $0,838^{\mathrm{c}}$ \\
P1A3 (Pati singkong karet 3\% + 15\% asam oleat) & $41,326^{\mathrm{a}}$ & $0,580^{\mathrm{ab}}$ \\
P2A1 (Pati singkong karet 4\% + 0\% lipid) & $55,236^{\mathrm{f}}$ & $0,687^{\mathrm{bc}}$ \\
P2A2 (Pati singkong karet 4\% + 15\% RBDPO) & $49,969^{\mathrm{e}}$ & $1,227^{\mathrm{de}}$ \\
P2A3 (Pati singkong karet 4\% + 15\% asam oleat) & $48,781^{\mathrm{de}}$ & $1,458^{\mathrm{f}}$ \\
P3A1 (Pati singkong karet 5\% + 0\% lipid) & $47,615^{\mathrm{cde}}$ & $1,147^{\mathrm{d}}$ \\
P3A2 (Pati singkong karet 5\% + 15\% RBDPO) & $44,843^{\mathrm{abc}}$ & $1,083^{\mathrm{d}}$ \\
P3A3 (Pati singkong karet 5\% + 15\% asam oleat) & $44,258^{\mathrm{abc}}$ & $1,337^{\mathrm{ef}}$ \\
\hline Keterangan: Angkanga &
\end{tabular}

Keterangan: Angka-angka yang diikuti oleh huruf yang sama menunjukkan perbedaan yang tidak nyata menurut Duncan a $5 \%$

Penambahan RBDPO (fraksi oleat) dan asam oleat pada berbagai konsentrasi pati singkong menunjukkan penurunan elastisitas. Menurut Rahim dkk. (2010), elongasi edible film cenderung menurun dengan meningkatnya konsentrasi minyak sawit. Penurunan elongasi diduga karena adanya interaksi kuat antara molekul pati dengan minyak sawit sehingga membentuk senyawa kompleks pati-lipida yang dapat menghambat pemanjangan film yang dihasilkan. Interaksi antara pati singkong karet dan lipid membentuk matriks yang tidak kontinyu dan kohesif sehingga edible film kurang dapat diperluas dan mengakibatkan elastisitas yang dihasilkan menurun. Chen et al. (2015) menyatakan bahwa pemanjangan film cellulose sulfate-oleic acid secara signifikan menurun ketika asam oleat dimasukkan ke dalam matriks. Lipid tidak dapat membentuk matriks yang kontinyu dan kohesif dalam film.

\section{Kuat Tarik}

Berdasarkan hasil penelitian diketahui bahwa terdapat interaksi antara konsentrasi pati singkong karet dan penambahan lipid terhadap kuat tarik edible film yang dihasilkan. Rerata kuat tarik edible film akibat konsentrasi pati singkong karet dengan penambahan RBDPO dan asam oleat disajikan pada Tabel 3.

Berdasarkan Tabel 3, diketahui bahwa kuat tarik terendah yaitu P1A3 dengan nilai 0,580 MPa. Sedangkan kuat tarik tertinggi yaitu pada perlakuan P3A1 dengan nilai 1,492 MPa. Peningkatan konsentrasi pati singkong karet memberi pengaruh yang nyata terhadap peningkatan nilai kuat tarik. Menurut 
Warkoyo dkk. (2014), konsentrasi pati yang ditambahkan semakin meningkat, maka kadar amilosa dalam larutan edible film semakin meningkat pula, akibatnya jumlah polimer dalam formasi matriks semakin banyak, ikatan antar polimer semakin kuat dan kuat tarik yang dihasilkan juga semakin besar. Kuat tarik yang semakin besar menunjukkan ketahanan terhadap kerusakan akibat peregangan dan tekanan semakin besar, sehingga kualitas fisik yang dihasilkan semakin baik. Penambahan RBDPO (fraksi oleat) dan asam oleat pada berbagai konsentrasi pati singkong mengakibatkan kuat tarik meningkat. Hal ini disebabkan karena lipid yang ditambahkan membentuk ikatan yang tidak kontinyu dan kohesif antara asam lemak pada lipid dan pati yang menyebabkan matriks film tidak kompak. Menurut Chen et al. (2015), peningkatan kadar asam oleat di bawah 15\% menghasilkan edible film dengan kuat tarik meningkat dan elongasi menurun. Kuat tarik yang tinggi dan elongasi yang rendah menunjukkan film yang dihasilkan bersifat kuat dan yang kurang dapat diperluas.

\section{Kelarutan}

Berdasarkan hasil penelitian diketahui bahwa tidak terdapat interaksi antara konsentrasi pati singkong karet dan penambahan lipid terhadap kelarutan edible film yang dihasilkan. Namun, perlakuan konsentrasi pati singkong karet dan penambahan RBDPO (fraksi oleat) dan asam oleat berpengaruh terhadap transparansi edible film yang dihasilkan. Reratanya disajikan pada Tabel 4. Perlakuan konsentrasi pati singkong karet $3 \%$ memiliki nilai kelarutan edible film terendah yakni $41,345 \%$. Perlakuan pati singkong karet 5\% memiliki persen kelarutan tertinggi yakni 46,493\%. Peningkatan konsentrasi pati singkong karet memberi pengaruh yang nyata terhadap peningkatan kelarutan edible film yang dihasilkan. Air sangat mudah untuk berikatan dengan protein dalam matrik edible film yang pada akhirnya membuat edible film mudah larut dalam air. Sifat hidrofilik alami protein dalam formulasi edible film mempermudah terjadinya interaksi dengan air, sehingga edible film mudah larut dalam air (Santoso dkk., 2004). Siswanti (2008) menambahkan bahwa peningkatan jumlah komponen yang bersifat hidrofilik diduga menyebabkan peningkatan prosentase kelarutan. 
Tabel 4. Rerata Kelarutan Edible Film oleh Konsentrasi Pati Singkong Karet

\begin{tabular}{ll}
\hline Perlakuan & Kelarutan (\%) \\
\hline P1 (Pati Singkong Karet 3\%) & $41,345^{\mathrm{a}}$ \\
P2 (Pati Singkong Karet 4\%) & $43,239^{\mathrm{ab}}$ \\
P3 (Pati Singkong Karet 5\%) & $46,493^{\mathrm{b}}$ \\
\hline
\end{tabular}

Keterangan: Angka-angka yang diikuti oleh huruf yang sama menunjukkan perbedaan yang tidak nyata menurut Duncan a 5\%

Penambahan RBDPO (fraksi oleat) dan asam oleat tidak memberikan pengaruh yang nyata terhadap kelarutan edible film yang dihasilkan. Rerata kelarutan edible film dengan penambahan lipid disajikan pada Gambar 1.

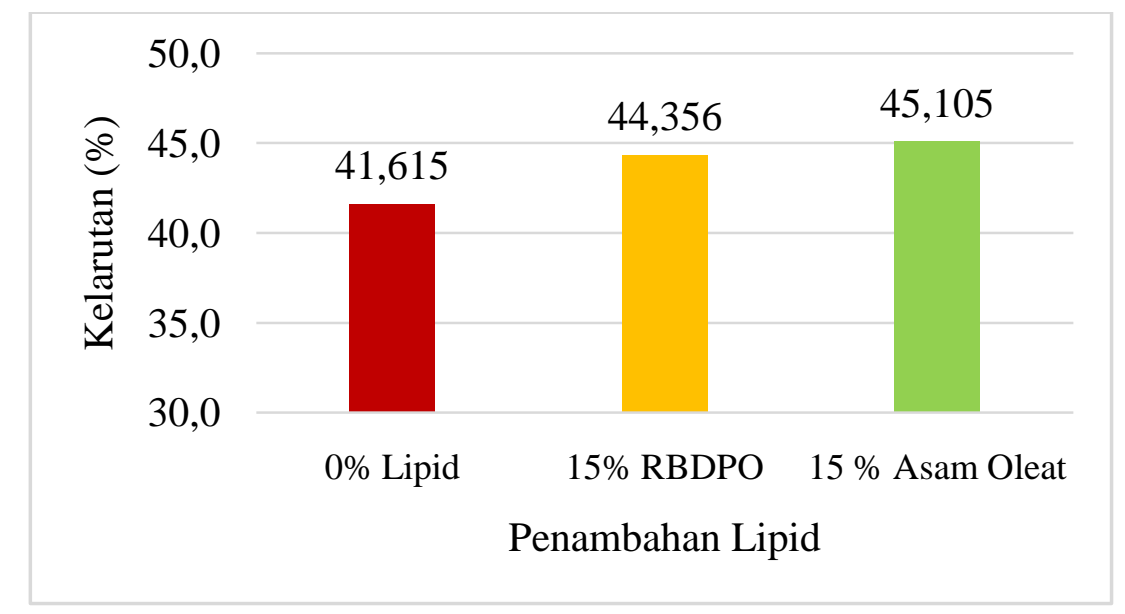

Gambar 1. Rerata Kelarutan Edible Film oleh Penambahan Fraksi Oleat dan Asam Oleat

Berdasarkan Gambar 2, rerata kelarutan edible film oleh penambahan RBDPO (fraksi oleat) dan asam oleat berkisar antara 41,615 - 45,105\%. Kelarutan yang semakin tinggi menunjukkan bahwa edible film semakin mudah terurai (degradable). Hal ini tidak sesuai dengan pendapat Murdianto (2005) bahwa penambahan komponen yang bersifat hidrofobik mengakibatkan film memiliki kelarutan yang rendah. Zahedi et al. (2011) menjelaskan bahwa film PGP (tanpa asam lemak) memiliki kelarutan tertinggi, dan penambahan zat hidrofobik mungkin bertanggung jawab atas penurunan kelarutan yang kecil. Hal ini diduga karena adanya kerusakan ikatan antarmolekul yang kuat dalam jaringan protein dan pembentukan ikatan rapuh dengan lipid mengakibatkan ketidakstabilan struktural. Oleh karena itu, film dengan penambahan lipid lebih rentan terhadap pembubaran. 


\section{Mikrostruktur}

Mikrotruktur edible film yang dibuat dari bahan pati singkong karet dengan penambahan RBDPO dan asam oleat ini diamati menggunakan mikroskop dengan perbesaran 400 kali. Hasil pengamatan terhadap penampakan permukaan edible film dari bahan pati singkong karet dengan penambahan RBDPO (fraksi oleat) dan asam oleat disajikan pada Gambar 2.

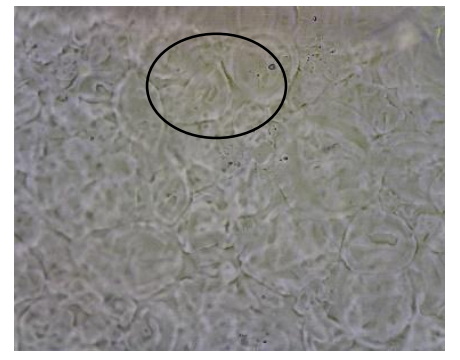

P1A1

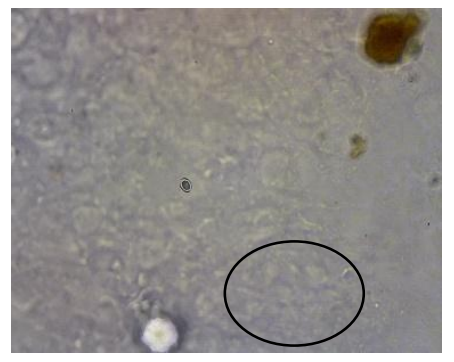

P2A1

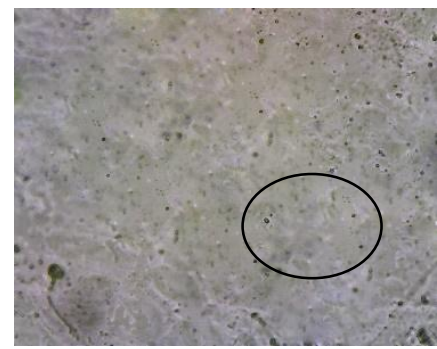

P3A1

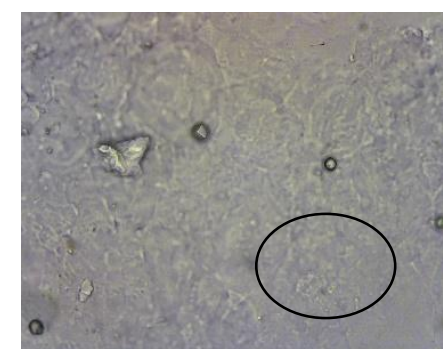

P1A2

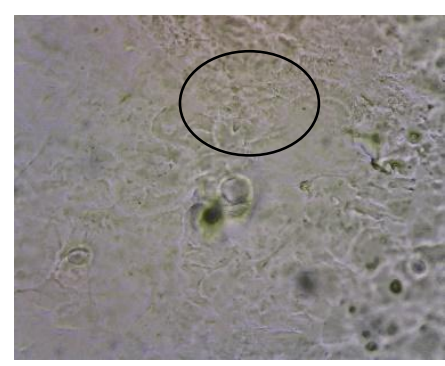

P2A2

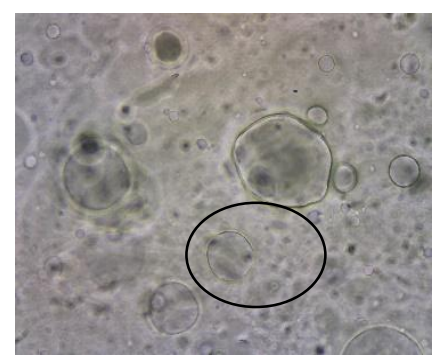

$\mathrm{P} 3 \mathrm{~A} 2$

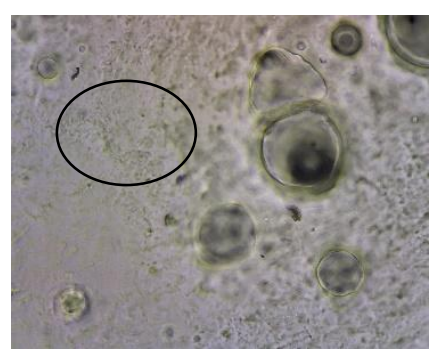

P1A3

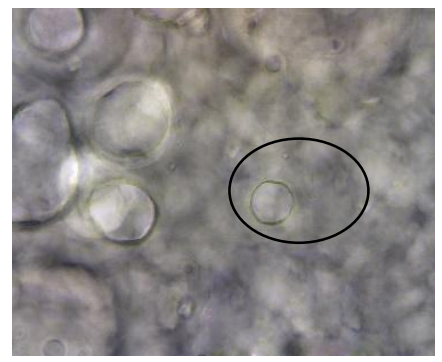

P2A3

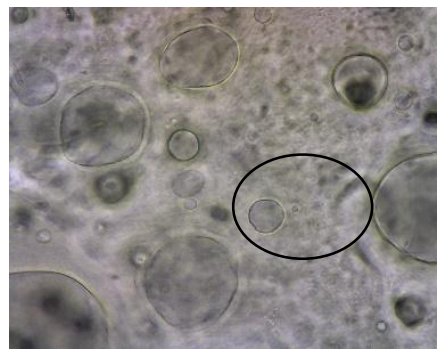

P3A3

Gambar 2. Foto Mikrostruktur Edible Film dengan Perbesaran 400 Kali

Semakin tinggi konsentrasi pati singkong karet yang ditambahkan maka edible film yang dihasilkan memiliki matriks yang semakin rapat, kompak dan padat yang ditunjukkan pada perlakuan P1A1, P2A1, dan P3A1. Menurut Hui (2006), dengan banyaknya struktur molekul yang terbentuk akibat penambahan pati kimpul dengan konsentrasi yang semakin tinggi menyebabkan edible film memiliki struktur yang lebih tertutup, yang artinya edible film tersebut tidak mudah dilewati oleh H2O, O2, dan CO2. Pamilia dkk. (2014) menambahkan bahwa peningkatan konsentrasi kitosan akan menyebabkan rongga-rongga pada lapisan edible film semakin sedikit sehingga akan memperkuat edible film. 
Penambahan RBDPO (fraksi oleat) dan asam oleat pada setiap konsentrasi pati singkong karet yang berbeda memberi hasil yang berbeda. Penambahan RBDPO (fraksi oleat) memberikan penampakan yang lebih kompak ketimbang pada penambahan asam oleat. Pada penambahan asam oleat dihasilkan lebih banyak globula lemak yang tidak terdispersi dengan baik dan tidak terlarut sempurna. Menurut Chen et al. (2015) bahwa mikrostruktur crosssectional film komposit selulosa sulfat dengan penambahan asam oleat lebih kasar daripada film kontrol. Film ini juga menunjukkan matriks mikro-retak dan pori-pori mikro dengan berbagai bentuk dan ukuran, yang berarti struktur matriks film berubah dengan penggabungan asam oleat.

\section{KESIMPULAN}

Berdasarkan hasil penelitian dapat diambil kesimpulan bahwa terjadi interaksi antara konsentrasi pati singkong karet dan penambahan fraksi oleat (RBDPO) dan asam oleat pada parameter elastisitas, kuat tarik dan laju transmisi uap air. Perlakuan konsentrasi pati berpengaruh nyata pada ketebalan, transparansi, kelarutan dan laju transmisi uap air. Penambahan fraksi oleat dan asam oleat berpengaruh pada ketebalan, transparansi, dan laju transmisi uap air. Perlakuan terbaik dihasilkan oleh P2A3 (4\% pati singkong karet $+15 \%$ asam oleat) yaitu dengan ketebalan $0,133 \mathrm{~mm}$, kuat tarik 1,458 MPa, elastisitas 48,781\%, kelarutan 44,035\% dan WVTR 17,246 g/m2.hari.

\section{REFERENSI}

Alves, V.D., Mali, S., Beleia, A. dan Grossmann, M.V.E. 2007. Effect of Glycerol and Amylase Enrichment on Cassava Starch Film Properties. Journal of Food Engineering. 78: 941-946.

Badan Litbang Pertanian. 2011. Inovasi Pengolahan Singkong Meningkatkan Pendapatan dan Divesifikasi Pangan. Sinartani Edisi 4-10 Mei 2011 No. 3404 Tahun XLI. $10 \mathrm{hlm}$.

Barus, S.P., 2002. Karakteristik Film Pati Biji Nangka (Artocarpus integra Meir) dengan Penambahan CMC. Skripsi. Biologi. Universitas Atma Jaya. Yogyakarta.

Chen G., B. Zhang and J. Zhao. 2015. Dispersion Process and Effect of Oleic Acid on Properties of Cellulose Sulfate-Oleic Acid Composite Film. Materials 2015, 8, 2346-2360

Falguera A, Quintero JP, Jimenez A, Munoz JA, dan Ibarz A. 2011. Edible Films and Coatings: Structures, Active Functions and Trends in Their Use. Article in Press. J Trends in Food Sci Tech. 20: 1-12.

Hawa, T. L., Imam T., dan Lilik E. R. 2015. Pengaruh Pemanfaatan Jenis dan Konsentrasi Lipid terhadap Sifat Fisik Edible Film Komposit Whey-Porang. J. Ilmu-Ilmu Peternakan 23 (1):35 - 43.

Hui, Y. H. 2006. Handbook of Food Science. Technology and Engineering Volume 1. CRC Press. USA. 
Murdianto. 2005. Sifat Fisik dan Mekanik Edible Film Ekstrak Daun Janggelan. Jurnal Agrosains. 18 (3) Juli 2005.

Pamilia C., Linda L., dan R. A. Mardiah. 2014. Pembuatan Film Plastik Bioedgradable dari Pati Jagung dengan Penambahan Kitosan dan Pemlastis Gliserol. Jurnal Teknik Kimia No. 4, Vol. 20 hal 26. Palembang: Jurusan Teknik Kimia Fakultas Teknik Universitas Sriwijaya.

Rahim, A., Nur A., Haryadi, dan Umar S. 2010. Pengaruh Konsentrasi Pati Aren dan Minyak Sawit terhadap Sifat Fisik dan Mekanik Edible Film. J. Agroland 17 (1) : $38-46$.

Santoso, B., D. Saputra, dan Pambayun. 2004. Kajian Teknologi Edible Coating dari Pati dan Aplikasinya untuk Pengemas Primer Lempok Durian. Jurnal Teknologi dan Industri Pangan Vol. XV No. 3, November 2004:239-243.

Siswanti. 2008. Karakteristik Edible Film dari Tepung Komposit Glukomanan Umbi Iles-Iles (Armophallus muelleri B.) dan Tepung Maizena. Skripsi UNS. Surakarta.

Syarifuddin, A dan Yunianta. 2015. Karakterisasi Edible Film dari Pektin Albedo Jeruk Bali dan Pati Garut. J. Pangan dan Agroindustri Vol.3 No.4 1538-1547

Tanaka, M., Ishizaki, S., Suzuki, T., and Takai, R. 2001. Water Vapour Permeability of Edible films Prepared from fish Water Soluble Proteins as Affected by Lipid Type. Journal of Tokyo University of Fisheries, 87, 31-37

Warkoyo, B. Rahardjo, D. W. Marseno, dan J. N. W. Karyadi. 2014. Sifat Fisik, Mekanik dan Barrier Edible Film Berbasis Pati Umbi Kimpul (Xanthosoma sagittifolium) yang Diinkorporasi dengan Kalium Sorbat. Agritech, Vol. 34, No. 1, Februari 2014.

Wiryawan, A. 2007. Kimia Analitik. Malang: Departemen Pendidikan Nasional.

Zahedi, Y., N. Sedaghat, and B. Ghanbarzadeh. 2011. Effect of Physical State of Fatty Acids on the Physical Properties of PGP-Based Emulsified Edible Film. International Journal of Nuts and Related Sciences 2 (2): 09-16. 